\title{
Variation in Onko Dialect of Yoruba
}

\author{
Gbenga Fakuade * \\ (University of Ilorin, Nigeria) \\ Lawal Tope Aminat ${ }^{* *}$ \\ (University of Ilorin, Nigeria) \\ Adewale Rafiu *** \\ (University of Ilorin, Nigeria)
}

\begin{abstract}
This paper examined variation in Onko dialect using the family tree model and the corresponding comparative method as the theoretical tool. A wordlist of basic items and a designed frame technique were used to gather data for this study. The data were presented in tables and the analyses were done through descriptive statistics. The data were analyzed to determine variation at the phonological, syntactic and lexical levels. The study revealed differences between Standard Yoruba and Onko dialect as well as the variation therein. Two basic factors discovered to be responsible for variations in Onko are geography (distribution of Onko communities) and language contact. The paper established that Onko exhibits variations, which are however not significant enough to disrupt mutual intelligibility among the speakers, and thus all the varieties remain a single dialect.
\end{abstract}

Keywords: variation, Onko dialect, Yoruba, family tree model, comparative method, triangulation

\section{Introduction}

One of the linguistics facts is that languages are systematic, and variation among their speakers is absolutely normal. Thus, language varies from one region to another, from one social group to another, and from one occasion or topic to another. Among the speakers of any language, there is variation in the way they use language. This variation is demonstrated by linguistic differences in terms of sounds (phonetics) and structure. There might be only slight variations between forms of a language such as a minor pronunciation

\footnotetext{
* Gbenga Fakuade: Professor of Linguistics, Department of Linguistics and Nigerian Languages, Faculty of Arts, University of Ilorin, Ilorin, Nigeria. E-mail: gbengusfakus@ yahoo.com.

** Lawal Tope Aminat: Doctoral student, Department of Linguistics and Nigerian Languages, Faculty of Arts, University of Ilorin, Ilorin, Nigeria. E-mail: hameenat735@gmail.com.

*** Adewale Rafiu: Associate Professor of Linguistics, Department of Linguistics and Nigerian Languages, Faculty of Arts, University of Ilorin, Ilorin, Nigeria. E-mail: rafenadewale@gmail.com.
} 


\section{Variation in Onko Dialect of Yoruba}

of words or a slight change of grammatical structure that do not inhibit intergroup communication.

Variation in languages is demonstrated by linguistic differences in pronunciation (accent), word choice (lexicon), or even preferences for particular grammatical patterns. Languages vary in many ways. One way of characterizing certain variations is to say that speakers of a particular language sometimes speak different dialects (Wardhaugh, 2006). Similarly, Holmes (2013) says that language varies according to its uses as well as its users, according to where it is used and to whom, as well as according to who is using it. Language variation according to its users is basically concerned with regional and social dialects, while language variation according to uses is based on the context of use; and in contextual use, we can talk of style, context and register. From the foregoing, different types of variation and the factors that govern it have been discussed in the literature: Regional variation (Trudgill \& Chambers, 1998; Britain, 1997; Winkler, 2002); Social variation (Gumperz, 1958; Wardhaugh, 2006; Holmes, 2013); Lexical variation (Rickford, 2002); Phonological variation (Wells, 1982; Arokoyo, 2012); and Grammatical variation (Holyk, n.d.).

For the purpose of this study, we adopted the family tree model and a corresponding comparative method. Comparative method is a technique for studying the development of languages by performing a feature-by-feature comparison of two or more languages with a common form or a shared ancestor. Ordinarily, this method is used to reconstruct prehistoric phases of languages to fill in gaps in the historical record of a language and other linguistic systems and to confirm or refute hypothesized relationships between languages. Comparative sociolinguistics, in particular, is concerned with the relationship of linguistic variation from one body of material to another. This requires a two-fold approach. First, a methodology that enables the many different influences on linguistic variation to be disentangled through a systematic examination of its patterns. Second, an approach that situates and explains linguistic variation through comparison with like features in related variety.

This study employed the triangulation technique as its methodological framework. Triangulation is often used to indicate that two or more methods are used in order to check the result. Triangulation is a powerful technique that facilitates the validation of data through cross verification from two or more sources. In particular, it refers to the application and combination of several research methodologies in the study of the same phenomenon. The study employs data triangulation (i.e., basic items gathering of 1,500 wordlists, and a designed frame technique), and methodological triangulation (i.e., interview and observation).

This method was used to, comparatively, access the convergent and divergent points 
among the distributions of the population of speakers of Onko dialect of Yoruba.

Onko dialect is spoken by the Oke Ogun people of Oyo State, Nigeria. Oke Ogun is located on the northern axis of Oyo State and -was formerly regarded as Oyo North in the Old Western Region. Given its geographical location, it is a gateway to the northern part of the country from the south. Oke Ogun, which literally means 'Upper Ogun', takes its identity from the famous Ogun River. Oke Ogun is bounded in the west by Barutin Local Government Area of Kwara State, Nigeria and Republic of Benin. On the East are Asa Local Government Area of Kwara State, Orire, Atiba and Oyo West Local Government Areas. To the north is Kaima Local Government Area of Kwara State, and to the south are Ibarapa East/North and Oyo West Local Government Area of Oyo State.

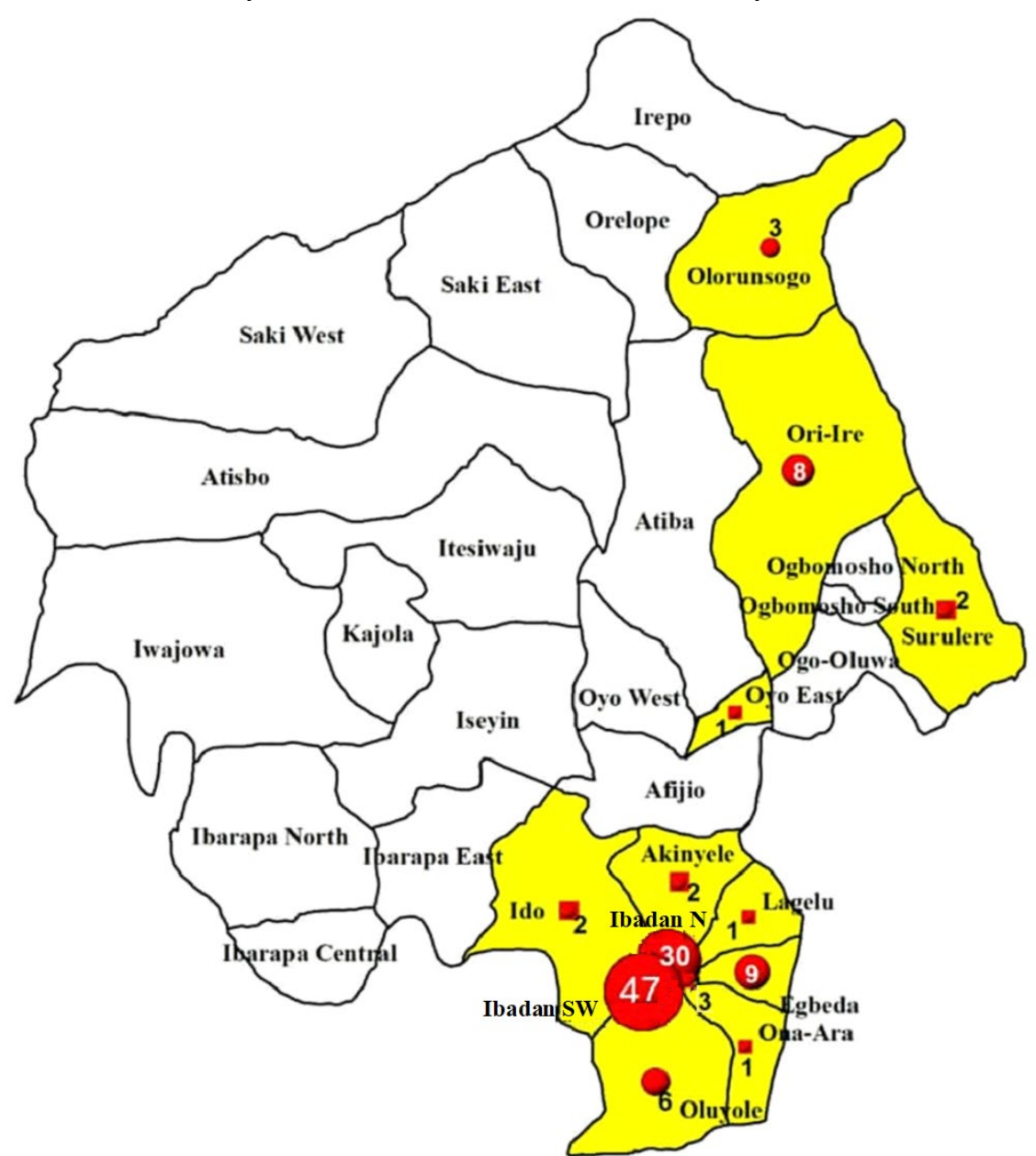

Figure 1. A map showing the ten (10) Local Government Areas that make up the Oke Ogun axis of Oyo State, Nigeria 
The landmass of Oke Ogun is about 13,537 square kilometers, which is about $54 \%$ of the total landmass of Oyo State. It has a population of about one and a half million and is composed of 10 Local Government Areas. The dialect is called Onko while the speakers are known as Oke Ogun people. Dialects of Yoruba have witnessed several classifications by scholars (see Adetugbo, 1982; Adeniyi, 2005). Onko dialect is classified under the northwest Yoruba. Figure 1 shows the map of the Oke Ogun Area where Onko dialect is spoken.

The most significant variations or differences within languages or dialects occur at the level of lexicon (vocabulary), phonology (pronunciation), and grammar (morphology and syntax). The data are therefore presented and analyzed at each of the linguistic levels to examine variation in Onko dialect. The data are presented in tables and the analyses are done through descriptive statistics. We further discuss the results of the study in relation to the focus of the study.

\section{Phonological variation in Onko dialect}

Phonological variation is concerned with sound differences within and across dialects. Phonological variation is also referred to as accent. According to Chambers \& Trudgill (1998), accent refers to a variety which is phonetically or phonologically different from other varieties. We compared the Standard Yoruba and the Onko varieties to examine phonological variation. But first, we examined the sound system of Onko dialect.

\subsection{Sound system of Onko dialect}

The sound system of a language or dialect includes an inventory of sounds and their features; it also includes rules that specify how sounds interact with each other. Below is the sound inventory of Onko dialect:

\subsubsection{Consonants in Onko dialect}

All the eighteen consonants attested in Standard Yoruba are also attested in Onko. In addition to these eighteen consonants however is the voiceless palato-alveolar affricate [ $\mathrm{t}]$ which is attested in the Onko variety spoken in Itesiwaju and Iwajowa LGAS. The alveolar trill $[\mathrm{r}]$ is often dropped or substituted with glottal fricative [h] in Iwajowa area. The consonant chart (Table 1) below shows the consonants of the varieties with the ones that are not common to all in parenthesis.

According to normal convention, consonants occur in different positions in a word. They occur in word-initial, word-medial (intervocalic) and word-final positions (Arokoyo, 2012). Looking through our data, the consonants in Onko can occur in all positions except word-final position. This implies that Onko does not allow closed syllables just like the Standard Yoruba. 
Gbenga Fakuade, Lawal Tope Aminat \& Adewale Rafiu

Table 1. Consonant chart of Onko dialect of Yoruba

\begin{tabular}{|c|c|c|c|c|c|c|c|c|}
\hline & Bi-labial & Labial dental & Alveolar & Palato-alveolar & Palatal & Velar & Labio-velar & Glottal \\
\hline Plosive & $\mathrm{b}$ & & $\mathrm{d}$ & & & $\mathrm{k}$ & $\mathrm{kp}$ & \\
\hline Fricative & & $\mathrm{f}$ & $\mathrm{s}$ & $\int$ & & & & $\mathrm{h}$ \\
\hline Affricate & & & & $(\mathrm{g})$ & & & & \\
\hline Lateral & & & 1 & & & & & \\
\hline Nasal & $\mathrm{m}$ & & $\mathrm{n}$ & & & & & \\
\hline Trill & & & $(\mathrm{r})$ & & & & & \\
\hline Approximant & $\mathrm{w}$ & & & & $\mathrm{j}$ & & & \\
\hline
\end{tabular}

2.1.2 Vowels in Onko dialect

Onko and Standard Yoruba operate the same vowel system. There are seven oral vowels and five nasal vowels. The distribution of these vowels is however different. The vowels of Onko and Standard Yoruba are presented in Figure 2.

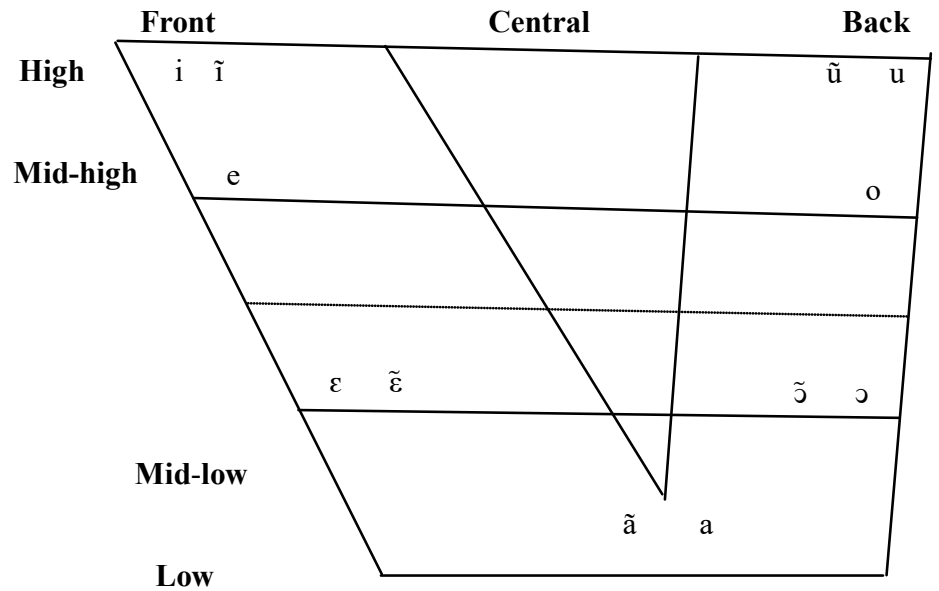

Figure 2. Vowel chart of Onko dialect

The seven oral vowels in Standard Yoruba can occur in all positions except for the back high rounded vowel $/ \mathrm{u} /$ which does not occur in the word-initial position. Similarly, all the varieties of Onko examined in this study do not allow vowel $/ \mathrm{u} /$ in word-initial position. It is however important to note that some vowels like /a, i, u/ and nasal vowels /ã, $\tilde{\mathrm{u}} /$ are subject to change. This change is conditioned by environment of occurrence. For instance, the high back rounded vowel $/ \mathrm{u} /$ often changes to mid-low back rounded vowel $/ \mathrm{s} /$ when it occurs after nasal consonants i.e. $[\mathrm{m}]$ and [n]. Instances of these occurrences are presented in the tables that follow. 


\section{Variation in Onko Dialect of Yoruba}

\subsubsection{Syllable structure of Onko dialect}

Onko dialect like all the other dialects of Yoruba language operates the open syllable system - CV type. From our data, we observed that Onko has the same syllable structure as Yoruba. They both have three syllable structures, namely the consonant vowel (CV), syllabic nasal $(\mathrm{N})$ and vowel alone $(\mathrm{V})$.

\subsection{Sound change}

A form of phonological variation observed in languages or dialects is sound change. According to Millar (2007:65), all types of change in pronunciation are collectively known as phonological change, or using a more traditional term, sound change. Phonological variation is said to occur when some sounds are realized differently in another variety. We therefore compared the Standard Yoruba and Onko dialect to examine change in the sequence of speech sounds representing the pronunciation of a particular word or a group of similar words. Below are tables to show the various sound changes observed in Onko dialect:

Table 2. $[\tilde{\mathrm{a}}] \sim[\tilde{\mathrm{e}}]$ variation in Onko

\begin{tabular}{l|l|c|c|c|c|c|c|c|c|l}
\hline No. & Word & $\begin{array}{c}\text { Standard } \\
\text { Yoruba }\end{array}$ & $\begin{array}{c}\text { Itesiwaju } \\
\text { LGA }\end{array}$ & $\begin{array}{c}\text { Iwajowa } \\
\text { LGA }\end{array}$ & $\begin{array}{c}\text { Iseyin } \\
\text { LGA }\end{array}$ & $\begin{array}{c}\text { Saki.West } \\
\text { LGA }\end{array}$ & $\begin{array}{c}\text { Kajola } \\
\text { LGA }\end{array}$ & $\begin{array}{c}\text { Atisbo } \\
\text { LGA }\end{array}$ & $\begin{array}{c}\text { Olorunsogo } \\
\text { LGA }\end{array}$ & Gloss \\
\hline 1 & okan & $\tilde{\mathrm{a}}$ & $\tilde{\varepsilon}$ & $\tilde{\varepsilon}$ & $\tilde{\varepsilon}$ & $\tilde{\varepsilon}$ & $\tilde{a}$ & $\tilde{\varepsilon}$ & $\tilde{\varepsilon}$ & heart \\
\hline 2 & eekanna & $\tilde{\mathrm{a}}$ & $\tilde{\varepsilon}$ & $\tilde{\varepsilon}$ & $\tilde{\varepsilon}$ & $\tilde{\varepsilon}$ & $\tilde{\mathrm{a}}$ & $\tilde{\varepsilon}$ & $\tilde{\varepsilon}$ & nails \\
\hline 3 & itan & $\tilde{\mathrm{a}}$ & $\tilde{\varepsilon}$ & $\tilde{\varepsilon}$ & $\tilde{\varepsilon}$ & $\tilde{\varepsilon}$ & $\tilde{\mathrm{a}}$ & $\tilde{\varepsilon}$ & $\tilde{\varepsilon}$ & thigh \\
\hline 4 & aguntan & $\tilde{\mathrm{a}}$ & $\tilde{\varepsilon}$ & $\tilde{\varepsilon}$ & $\tilde{\varepsilon}$ & $\tilde{\varepsilon}$ & $\tilde{\mathrm{a}}$ & $\tilde{\varepsilon}$ & $\tilde{\varepsilon}$ & sheep \\
\hline 5 & iyan & $\tilde{\mathrm{a}}$ & $\tilde{\varepsilon}$ & $\tilde{\varepsilon}$ & $\tilde{\varepsilon}$ & $\tilde{\varepsilon}$ & $\tilde{\varepsilon}$ & $\tilde{\varepsilon}$ & $\tilde{\varepsilon}$ & pounded yam \\
\hline 6 & eyan & $\tilde{\mathrm{a}}$ & $\tilde{\varepsilon}$ & $\tilde{\varepsilon}$ & $\tilde{\varepsilon}$ & $\tilde{\varepsilon}$ & $\tilde{\varepsilon}$ & $\tilde{\varepsilon}$ & $\tilde{\varepsilon}$ & human \\
\hline 7 & ina & $\tilde{\mathrm{a}}$ & $\tilde{\varepsilon}$ & $\tilde{\varepsilon}$ & $\tilde{\varepsilon}$ & $\tilde{\varepsilon}$ & $\tilde{\varepsilon}$ & $\tilde{\varepsilon}$ & $\tilde{\varepsilon}$ & fire \\
\hline 8 & gbona & $\tilde{\mathrm{a}}$ & $\tilde{\varepsilon}$ & $\tilde{\varepsilon}$ & $\tilde{\varepsilon}$ & $\tilde{\varepsilon}$ & $\tilde{\varepsilon}$ & $\tilde{\varepsilon}$ & $\tilde{\varepsilon}$ & hot \\
\hline 9 & eran & $\tilde{\mathrm{a}}$ & $\tilde{\varepsilon}$ & $\tilde{\varepsilon}$ & $\tilde{\varepsilon}$ & $\tilde{\varepsilon}$ & $\tilde{\varepsilon}$ & $\tilde{\varepsilon}$ & $\tilde{\varepsilon}$ & meat \\
\hline 10 & $\operatorname{ranti}$ & $\tilde{\mathrm{a}}$ & $\tilde{\varepsilon}$ & $\tilde{\varepsilon}$ & $\tilde{\varepsilon}$ & $\tilde{\varepsilon}$ & $\tilde{\varepsilon}$ & $\tilde{\varepsilon}$ & $\tilde{\varepsilon}$ & remember \\
\hline 11 & osan & $\tilde{\mathrm{a}}$ & $\tilde{\varepsilon}$ & $\tilde{\varepsilon}$ & $\tilde{\varepsilon}$ & $\tilde{\varepsilon}$ & $\tilde{\varepsilon}$ & $\tilde{\varepsilon}$ & $\tilde{\varepsilon}$ & orange \\
\hline 12 & sanwo & $\tilde{\mathrm{a}}$ & $\tilde{\varepsilon}$ & $\tilde{\varepsilon}$ & $\tilde{\varepsilon}$ & $\tilde{\varepsilon}$ & $\tilde{\varepsilon}$ & $\tilde{\varepsilon}$ & $\tilde{\varepsilon}$ & pay \\
\hline
\end{tabular}

Table 2 shows that the low nasal unrounded vowel [ã] in standard Yoruba is often realized as the mid-low nasal unrounded vowel [ $\tilde{\varepsilon}]$ in most of the varieties of Onko. Therefore, this sound change is a common feature of all the Onko varieties under study. However, an exception is observed in the variety spoken in Kajola LGA. From number 1 to 4 , one can observe that vowel [ã] does not change after the voiceless velar and voiceless alveolar stop in the variety spoken around Kajola LGA. This is largely due to the fact that the pronunciation of these words has overshadowed the variety of pronunciation. Tables 


\section{Gbenga Fakuade, Lawal Tope Aminat \& Adewale Rafiu}

3-7 further show these variations across the communities of Onko speakers.

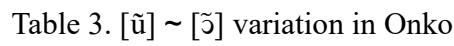

\begin{tabular}{|c|c|c|c|c|c|c|c|c|c|c|}
\hline No. & Word & $\begin{array}{c}\text { Standard } \\
\text { Yoruba } \\
\end{array}$ & $\begin{array}{c}\text { Itesiwaju } \\
\text { LGA } \\
\end{array}$ & $\begin{array}{c}\text { Iwajowa } \\
\text { LGA }\end{array}$ & $\begin{array}{c}\text { Iseyin } \\
\text { LGA }\end{array}$ & $\begin{array}{c}\text { Saki West } \\
\text { LGA } \\
\end{array}$ & \begin{tabular}{|c|} 
Kajola \\
LGA
\end{tabular} & $\begin{array}{c}\text { Atisbo } \\
\text { LGA } \\
\end{array}$ & $\begin{array}{c}\text { Olorunsogo } \\
\text { LGA } \\
\end{array}$ & Gloss \\
\hline 1 & kun & $\tilde{\mathrm{u}}$ & ว & ว & ๊ & ว & $\tilde{\mathrm{u}}$ & $\tilde{\mathrm{u}}$ & $\tilde{\mathrm{u}}$ & full \\
\hline 2 & kunle & ũ & $\tilde{\jmath}$ & $\tilde{\jmath}$ & $\tilde{\jmath}$ & ว & $\tilde{\mathrm{u}}$ & $\tilde{\mathrm{u}}$ & $\tilde{\mathrm{u}}$ & kneel \\
\hline 3 & okunrin & $\tilde{\mathrm{u}}$ & ว & $\tilde{\jmath}$ & $\tilde{\jmath}$ & ว & ј & $\tilde{\mathrm{u}}$ & $\tilde{\mathrm{u}}$ & male \\
\hline 4 & irun & $\tilde{\mathrm{u}}$ & ว & $\tilde{\jmath}$ & ว & $\tilde{\jmath}$ & $\tilde{\mathrm{u}}$ & $\tilde{\mathrm{u}}$ & $\tilde{\mathrm{u}}$ & hair \\
\hline 5 & orun & $\tilde{\mathrm{u}}$ & ว & $\tilde{\jmath}$ & $\tilde{\jmath}$ & ว & $\tilde{\mathrm{u}}$ & $\tilde{\mathrm{u}}$ & $\tilde{\mathrm{u}}$ & neck \\
\hline 6 & irungbon & $\tilde{\mathrm{u}}$ & ว & ว & $\tilde{\jmath}$ & $\tilde{\jmath}$ & $\tilde{\jmath}$ & $\tilde{\mathrm{u}}$ & ũ & beard \\
\hline 7 & odun & $\tilde{\mathrm{u}}$ & ว & ว & $\tilde{\jmath}$ & $\tilde{\jmath}$ & $\tilde{\mathrm{u}}$ & $\tilde{\mathrm{u}}$ & $\tilde{\mathrm{u}}$ & year \\
\hline 8 & adun & $\tilde{\mathrm{u}}$ & ว & ว & ว & ว & $\tilde{\mathrm{u}}$ & $\tilde{\mathrm{u}}$ & $\tilde{\mathrm{u}}$ & sweet \\
\hline 9 & $d u n$ & $\tilde{\mathrm{u}}$ & ว & $\tilde{\jmath}$ & ว & ว & $\tilde{\mathrm{u}}$ & $\tilde{\mathrm{u}}$ & $\tilde{\mathrm{u}}$ & sweet \\
\hline 10 & otun & ũ & ว & ว & ว & $\tilde{\jmath}$ & $\tilde{\mathrm{u}}$ & ũ & $\tilde{\mathrm{u}}$ & right \\
\hline 11 & tuntun & $\tilde{\mathrm{u}}$ & $\tilde{\jmath}$ & ј & $\tilde{\jmath}$ & $\tilde{\jmath}$ & $\tilde{\mathrm{u}}$ & ũ & $\tilde{\mathrm{u}}$ & new \\
\hline
\end{tabular}

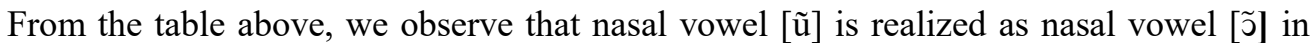
Onko. This is however not so in Atisbo and Olorunsogo LGAS. This sound change is also minimal in Kajola, and the change is noticed in number 3 and 6 where we have okonrin 'man' and irogbon 'beard'.

Table 4. $[\mathrm{u}] \sim[0]$ variation in Onko

\begin{tabular}{|c|c|c|c|c|c|c|c|c|c|c|}
\hline No. & Word & $\begin{array}{c}\text { Standard } \\
\text { Yoruba } \\
\end{array}$ & \begin{tabular}{|c} 
Itesiwaju \\
LGA \\
\end{tabular} & $\begin{array}{c}\text { Iwajowa } \\
\text { LGA } \\
\end{array}$ & \begin{tabular}{|l} 
Iseyin \\
LGA
\end{tabular} & $\begin{array}{c}\text { Saki west } \\
\text { LGA }\end{array}$ & \begin{tabular}{|c|} 
Kajola \\
LGA
\end{tabular} & \begin{tabular}{|c|} 
Atisbo \\
LGA
\end{tabular} & $\begin{array}{c}\text { Olorunsogo } \\
\text { LGA }\end{array}$ & Gloss \\
\hline 1 & imu & $\tilde{\mathrm{u}}$ & $\tilde{\jmath}$ & $\tilde{\jmath}$ & $\tilde{\jmath}$ & $\tilde{\jmath}$ & $\tilde{\mathrm{u}}$ & $\tilde{\mathrm{u}}$ & $\tilde{\mathrm{u}}$ & nose \\
\hline 2 & $\underline{e} \underline{\underline{u}} \underline{\underline{u}}$ & $\tilde{\mathrm{u}}$ & $\tilde{\jmath}$ & $\tilde{\jmath}$ & $\tilde{\jmath}$ & $\tilde{\jmath}$ & $\tilde{\mathrm{u}}$ & $\tilde{\mathrm{u}}$ & $\tilde{\mathrm{u}}$ & palm wine \\
\hline 3 & $m u$ & $\tilde{\mathrm{u}}$ & $\tilde{\jmath}$ & $\tilde{\jmath}$ & $\tilde{\jmath}$ & $\tilde{\jmath}$ & $\tilde{\mathrm{u}}$ & $\tilde{\mathrm{u}}$ & $\tilde{\mathrm{u}}$ & take \\
\hline 4 & alaamu & $\tilde{\mathrm{u}}$ & $\tilde{\jmath}$ & $\tilde{\jmath}$ & $\tilde{\jmath}$ & $\tilde{\jmath}$ & $\tilde{\mathrm{u}}$ & $\tilde{\mathrm{u}}$ & $\tilde{\mathrm{u}}$ & lizard \\
\hline 5 & оти & $\tilde{\mathrm{u}}$ & $\tilde{\jmath}$ & $\tilde{\jmath}$ & $\tilde{\jmath}$ & $\tilde{\jmath}$ & $\tilde{\mathrm{u}}$ & $\tilde{\mathrm{u}}$ & $\tilde{\mathrm{u}}$ & breast \\
\hline 6 & inu & $\tilde{\mathrm{u}}$ & $\tilde{\jmath}$ & $\tilde{\jmath}$ & $\tilde{\jmath}$ & $\tilde{\jmath}$ & $\tilde{\mathrm{u}}$ & $\tilde{\mathrm{u}}$ & $\tilde{\mathrm{u}}$ & stomach \\
\hline 7 & sоnu & $\tilde{\mathrm{u}}$ & $\tilde{\jmath}$ & $\tilde{\jmath}$ & $\tilde{\jmath}$ & $\tilde{\jmath}$ & $\tilde{\mathrm{u}}$ & $\tilde{\mathrm{u}}$ & $\tilde{\mathrm{u}}$ & lose \\
\hline
\end{tabular}

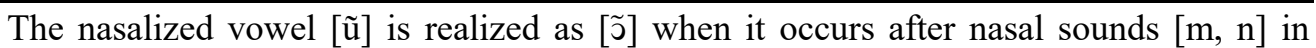
Onko with an exception in the varieties spoken in Kajola, Atisbo and Olorunsogo LGAS.

Table 5 shows that The front high unrounded vowel [i] is often nasalized as [î] in Onko when it occurs in word-medial or word-final position. This sound change is common to all the Onko varieties examined in this study. 
Variation in Onko Dialect of Yoruba

Table 5. [i] [ĩ] variation in Onko

\begin{tabular}{|c|c|c|c|c|c|c|c|c|c|c|}
\hline No. & Word & $\begin{array}{c}\text { Standard } \\
\text { Yoruba }\end{array}$ & $\begin{array}{c}\text { Itesiwaju } \\
\text { LGA }\end{array}$ & $\begin{array}{c}\text { Iwajowa } \\
\text { LGA }\end{array}$ & $\begin{array}{l}\text { Iseyin } \\
\text { LGA }\end{array}$ & $\begin{array}{c}\text { Saki west } \\
\text { LGA }\end{array}$ & $\begin{array}{c}\text { Kajola } \\
\text { LGA }\end{array}$ & $\begin{array}{c}\text { Atisbo } \\
\text { LGA }\end{array}$ & $\begin{array}{c}\text { Olorunsogo } \\
\text { LGA }\end{array}$ & Gloss \\
\hline 1 & si & $\mathrm{i}$ & $\tilde{1}$ & $\tilde{1}$ & $\tilde{1}$ & $\tilde{1}$ & $\tilde{1}$ & $\tilde{1}$ & $\tilde{1}$ & open \\
\hline 2 & fesi & $\mathrm{i}$ & $\tilde{1}$ & $\tilde{1}$ & $\tilde{1}$ & $\tilde{1}$ & $\tilde{1}$ & $\tilde{1}$ & $\tilde{1}$ & reply \\
\hline 3 & $e j i$ & $\mathrm{i}$ & $\tilde{1}$ & $\tilde{1}$ & $\tilde{1}$ & $\tilde{1}$ & $\tilde{1}$ & $\tilde{1}$ & $\tilde{1}$ & two \\
\hline 4 & mejila & $\mathrm{i}$ & $\tilde{1}$ & $\tilde{1}$ & $\tilde{1}$ & $\tilde{1}$ & $\tilde{1}$ & $\tilde{1}$ & $\tilde{1}$ & twelve \\
\hline 5 & ogoji & $\mathrm{i}$ & $\tilde{1}$ & $\tilde{1}$ & $\tilde{1}$ & $\tilde{1}$ & $\tilde{1}$ & $\tilde{1}$ & $\tilde{1}$ & forty \\
\hline
\end{tabular}

Table 6. [ĩ $] \sim[\mathrm{n}]$ variation in Onko dialect

\begin{tabular}{c|l|c|c|c|c|c|c|c|c|l}
\hline No. & Word & $\begin{array}{c}\text { Standard } \\
\text { Yoruba }\end{array}$ & $\begin{array}{c}\text { Itesiwaju } \\
\text { LGA }\end{array}$ & $\begin{array}{c}\text { Iwajowa } \\
\text { LGA }\end{array}$ & $\begin{array}{c}\text { Iseyin } \\
\text { LGA }\end{array}$ & $\begin{array}{c}\text { Saki west } \\
\text { LGA }\end{array}$ & $\begin{array}{c}\text { Kajola } \\
\text { LGA }\end{array}$ & $\begin{array}{c}\text { Atisbo } \\
\text { LGA }\end{array}$ & $\begin{array}{c}\text { Olorunsogo } \\
\text { LGA }\end{array}$ & Gloss \\
\hline 1 & igba & $\tilde{\mathrm{i}}$ & $\mathrm{n}$ & $\mathrm{n}$ & $\mathrm{n}$ & $\mathrm{n}$ & $\mathrm{n}$ & $\mathrm{n}$ & $\mathrm{n}$ & time \\
\hline 2 & ise & $\tilde{\mathrm{i}}$ & $\mathrm{n}$ & $\mathrm{n}$ & $\mathrm{n}$ & $\mathrm{n}$ & $\mathrm{n}$ & $\mathrm{n}$ & $\mathrm{n}$ & work \\
\hline 3 & ile & $\tilde{\mathrm{i}}$ & $\mathrm{n}$ & $\mathrm{n}$ & $\mathrm{n}$ & $\mathrm{n}$ & $\mathrm{n}$ & $\mathrm{n}$ & $\mathrm{n}$ & house \\
\hline 4 & irawo & $\tilde{\mathrm{i}}$ & $\mathrm{n}$ & $\mathrm{n}$ & $\mathrm{n}$ & $\mathrm{n}$ & $\mathrm{n}$ & $\mathrm{n}$ & $\mathrm{n}$ & star \\
\hline 5 & igbe & $\tilde{\mathrm{i}}$ & $\mathrm{n}$ & $\mathrm{n}$ & $\mathrm{n}$ & $\mathrm{n}$ & $\mathrm{n}$ & $\mathrm{n}$ & $\mathrm{n}$ & faeces \\
\hline
\end{tabular}

From Table 6, we observe that The front high unrounded vowel [i] changes to alveolar nasal $[\mathrm{n}]$ when it occurs in word-initial position.

Table 7. [S] [tg] variation in Onko dialect

\begin{tabular}{|c|c|c|c|c|c|c|c|c|c|c|}
\hline No. & Word & $\begin{array}{c}\text { Standard } \\
\text { Yoruba }\end{array}$ & $\begin{array}{c}\text { Itesiwaju } \\
\text { LGA }\end{array}$ & $\begin{array}{c}\text { Iwajowa } \\
\text { LGA }\end{array}$ & $\begin{array}{c}\text { Iseyin } \\
\text { LGA }\end{array}$ & $\begin{array}{c}\text { Saki west } \\
\text { LGA }\end{array}$ & $\begin{array}{c}\text { Kajola } \\
\text { LGA }\end{array}$ & $\begin{array}{c}\text { Atisbo } \\
\text { LGA }\end{array}$ & $\begin{array}{c}\text { Olorunsogo } \\
\text { LGA }\end{array}$ & Gloss \\
\hline 1 & $i \underline{s} e$ & $\int$ & t5 & tf & $\int$ & $\int$ & $\int$ & $\int$ & $\int$ & work \\
\hline 2 & asale & $\int$ & tf & tf & $\int$ & $\int$ & $\int$ & $\int$ & $\int$ & dawn \\
\hline 3 & $i \underline{s} u$ & $\int$ & t5 & tf & $\int$ & $\int$ & $\int$ & $\int$ & $\int$ & yam \\
\hline 4 & os $\underline{\text { upa }}$ & $\int$ & tf & ts & $\int$ & $\int$ & $\int$ & $\int$ & $\int$ & moon \\
\hline 5 & es in & $\int$ & t5 & t5 & $\int$ & $\int$ & $\int$ & $\int$ & $\int$ & horse \\
\hline 6 & $a \underline{s} a$ & $\int$ & tf & tf & $\int$ & $\int$ & $\int$ & $\int$ & $\int$ & hawk \\
\hline 7 & $\underline{s} u b u$ & $\int$ & t & t5 & $\int$ & $\int$ & $\int$ & $\int$ & $\int$ & fall \\
\hline 8 & sere & $\int$ & ts & ts & $\int$ & $\int$ & $\int$ & $\int$ & $\int$ & play \\
\hline 9 & aso & $\int$ & $\mathrm{t}$ & $\mathfrak{t}$ & $\int$ & $\int$ & $\int$ & $\int$ & $\int$ & cloth \\
\hline
\end{tabular}

The voiceless palate-alveolar fricative $\left[\int\right]$ is realized as voiceless palato-alveolar affricate $[\mathrm{t}]$ in Onko. This sound change is however peculiar to two local government areas which are Itesiwaju and Iwajowa. The remaining five varieties adopt the voiceless palato-alveolar fricative just like in the Standard Yoruba.

\subsection{Sound loss}




\section{Gbenga Fakuade, Lawal Tope Aminat \& Adewale Rafiu}

Another type of phonological variation observed in our data is sound loss. The data revealed that the alveolar trill $[\mathrm{r}]$ is often deleted or substituted with glottal fricative in Iwajowa LGA. Table 8 shows the manifestation of sound loss, and alternative sound use in words within the community of Onko speakers at large.

Table 8 . Sound loss and alternation in varieties of Onko dialect

\begin{tabular}{|c|c|c|c|c|c|c|c|c|c|}
\hline No. & $\begin{array}{c}\text { Standard } \\
\text { Yoruba }\end{array}$ & $\begin{array}{c}\text { Itesiwaju } \\
\text { LGA }\end{array}$ & $\begin{array}{c}\text { Iwajowa } \\
\text { LGA }\end{array}$ & $\begin{array}{c}\text { Kajola } \\
\text { LGA }\end{array}$ & $\begin{array}{c}\text { Iseyin } \\
\text { LGA }\end{array}$ & $\begin{array}{c}\text { Saki west } \\
\text { LGA }\end{array}$ & $\begin{array}{c}\text { Atisbo } \\
\text { LGA }\end{array}$ & $\begin{array}{c}\text { Olorunsogo } \\
\text { LGA }\end{array}$ & Gloss \\
\hline 1 & ori & eri & $e i$ & ori & eri & eri & ori & eri & head \\
\hline 2 & ahon & ahon & ahon & ahun & ahon & ahun & ahun & ahun & tongue \\
\hline 3 & irun & iron & ion & irun & iron & iron & irun & irun & hair \\
\hline 4 & fun & fon & fon & fon & fon & fon & fun & fun & wring \\
\hline 5 & tuntun & tonton & titon & tuntun & titon & tuntun & titon & tuntun & new \\
\hline 6 & оти & omo & omo & оти & omo & omo & oyun & оти & breast \\
\hline 7 & inu & Ino & ino & inu & ino & ino & Inu & inu & stomach \\
\hline 8 & $i m u$ & imo & imo & $i m u$ & imo & imo & imu & $i m u$ & nose \\
\hline 9 & kanga & kenga & kenga & kanga & kenga & kenga & kenga & kenga & well \\
\hline 10 & okan & oken & oken & okan & oken & oken & oken & oken & heart \\
\hline 11 & osan & osen & osen & osen & osen & osen & osen & osen & orange \\
\hline 12 & eran & eren & een & eren & eren & eren & eren & eren & meat \\
\hline 13 & $s i$ & chin & chinin & $\sin$ & $\sin$ & $\sin$ & $\sin$ & $\sin$ & open \\
\hline 14 & asa & acha & acha & asa & asa & asa & asa & asa & vulture \\
\hline 15 & ise & nche & nche & nse & nse & nse & nse & nse & work \\
\hline 16 & $i s u$ & $i c h u$ & $i c h u$ & $i s u$ & $i s u$ & $i s u$ & $i s u$ & $i s u$ & yam \\
\hline 17 & orunkun & eekun & eekun & orunkun & eekun & eekun & erikun & eekun & knee \\
\hline 18 & eruku & oeku & eeku & eeku & eeku & eeku & eeku & eeku & dust \\
\hline 19 & oruko & ooko & ooko & ooko & ooko & ooko & ooko & ooko & name \\
\hline 20 & obuko & ooko & ooko & ooko & ooko & ooko & ooko & ooko & he goat \\
\hline
\end{tabular}

From Table 8, the variation observed is phonological in nature. This is because the words differ in respect to their phonological component. The word ori 'head' is realized as eri 'head' in Onko variety with the exception of Kajola and Atisbo LGAs and ahon 'tongue' in Standard Yoruba is realized as ahun 'tongue' in Iseyin and Iwajowa LGAs. In number 3 to 8, the Standard Yoruba, Kajola, Atisbo and Olorunsogo share similar segmental distribution and concatenation in words like irun 'hair', fun 'wring', tuntun 'new', oти 'breast', inu 'stomach', imu 'nose' as against the other four varieties.

All the Onko varieties are similar in number 9-12: kenga 'well', oken 'heart', osen 


\section{Variation in Onko Dialect of Yoruba}

'orange', eren 'meat' with the exception of Kajola LGA which is the same as Yoruba i.e., kanga 'well' and okan 'heart'.

From number 13 to 16, Itesiwaju and Kajola are similar while in 13 and 15 the remaining five varieties are similar. Then in 14 and 16, Standard Yoruba, Kajola, Atisbo, Olorunsogo, Iseyin and Saki West are similar. The table also shows that the words orunkun 'knee', eruku 'dust', oruko 'name' and obuko 'he goat' are realized as eekun 'knee', eeku 'dust', ooko 'name' and ooko 'he-goat' in Onko. This observation brings us to the behavioural pattern of some sounds in fast speech as noticed in Onko dialect and Standard Yoruba.

The central alveolar liquid $/ \mathrm{r} /$ is guided by certain rules in Standard Yoruba, namely, (i) delete $/ \mathrm{r} /$ if it occurs between two identical vowels in a word; and (ii) in intervocalic position, delete $/ \mathrm{r} /$ if it is followed by a high vowel (Oyebade, 2001). However, /r/ cannot be elided if it is the only consonantal segment in a word. Contrary to this operation in the Standard Yoruba, Kajola and Itesiwaju varieties of Onko dialect still delete $/ \mathrm{r} /$ even if it is the only consonant. This is a case of overgeneralization, probably due to proximity of these two varieties to Benin Republic where different languages are spoken and encountered by the speakers.

The influence of foreign languages is equally advanced for the presence of the voiceless alveo-palatal affricate $/ \mathfrak{g} /$ in the Itesiwaju and Iwajowa varieties $-/ \mathrm{f} /$ is not attested to in the Standard Yoruba. The realization of $/ \mathrm{n} / \mathrm{in}$ Onko dialect in general is a common phonological feature. It is used in Onko in the place of $/ \mathrm{i} /$ in the word-initial position. While one may be tempted to refer to the consonant that follows $/ \mathrm{n} /$ as prenasalized, e.g., $n c h e \ln f \varepsilon /$, the consonant is indeed a syllabic nasal which attests to the fact that Yoruba does not permit consonant cluster.

\section{Grammatical variation}

Grammatical variation involves two subtypes: morphology and syntax (Rickford, 2002:4). Both morphology and syntax are major components of grammar. In the course of our data analysis, we discovered that Yoruba and Onko are very similar in terms of their morphological component and since our focus is on variation, discussing the morphological component of Onko dialect would amount to unnecessary repetition, and thus we focused on syntactic variation.

Syntactic variation involves differences in sentence formation among languages and dialects. To examine syntactic variation in Onko and Yoruba, we compared some questions and sentences. First, we examined the word order in Onko and our study revealed that Onko exhibits the same word order with Yoruba. This implies that Onko also exhibits the SVO word order. Examples are presented below: 


\section{Standard Yoruba}

(1) a. Mo je isu

$1 \mathrm{sg}$ eat yam

'I ate yam.'

b. Ode pa okete

Hunter kill bush rat

'The hunter killed a bush rat.'

c. Mo feran efo

$1 \mathrm{sg}$ like vegetable

'I like vegetable.'

The three sentences above are presented in each variety in Table 9 to examine the word order in Onko.

Table 9. Word order in Onko

\begin{tabular}{c|c|c|c|c|c|l|l}
\hline $\begin{array}{c}\text { Itesiwaju } \\
\text { LGA }\end{array}$ & $\begin{array}{c}\text { Iwajowa } \\
\text { LGA }\end{array}$ & $\begin{array}{c}\text { Kajola } \\
\text { LGA }\end{array}$ & $\begin{array}{c}\text { Iseyin } \\
\text { LGA }\end{array}$ & $\begin{array}{c}\text { Saki West } \\
\text { LGA }\end{array}$ & $\begin{array}{c}\text { Atisbo } \\
\text { LGA }\end{array}$ & $\begin{array}{c}\text { Olorunsogo } \\
\text { LGA }\end{array}$ & Gloss \\
\hline Mo je ichu. & Mo je ichu. & Mo je isu. & Mo je isu. & Mo je isu. & Mo je isu. & Mo je isu. & I ate yam. \\
\hline Ode pa okete. & Ode pa okete. & Ode pa ogon. & Ode pa okete. & Ode pa okete. & Ode pa okete. & Ode pa okete. & $\begin{array}{l}\text { The hunter } \\
\text { killed a bush rat. }\end{array}$ \\
\hline Mo feren efo. & Mo fehen efo. & Mo feren efo. & Mo feren efo. & Mo feren efo. & Mo feren efo. & Mo feren efo. & I like vegetable. \\
\hline
\end{tabular}

We discovered that some grammatical features like question and negative markers in Yoruba have distinct variants in Onko. The question markers se 'have', kinni 'what', nigbawo 'when' and nibo 'where' as well as the negative marker má 'don't' in Yoruba are examined in Onko. Data are presented below along with the analysis:

Iwajowa Variety

(2) a. Cho $t i \quad$ lo

AUX-2sg PERF go

'Have you gone?'

b. $\mathrm{Ki} \quad \mathrm{o}$ je losen yii

What 2sg-Pro eat afternoon this

'What did you eat this afternoon?'

c. Ngbawo lo de a

When 2sg-Pro arrive expletive

'When did you arrive?'

d. Nbo $o \quad t i \quad n \quad b o$

Where 2sg-Pro ASP CONT come

'Where are you coming from?' 


\section{Variation in Onko Dialect of Yoruba}

\section{Itesiwaju Variety}

(3) a. Cho ti lo

AUX-2sg PERF go

'Have you gone?'

b. Ki lo je losen yii

What 2sg-Pro eat afternoon this

'What did you eat this afternoon?'

c. Ngbawo lo a de

When 2sg-Pro expletive arrive

'When did you arrive?'

$\begin{array}{lllll}\text { d. } N b o & \text { lo } & t i & n & b o\end{array}$

Where 2sgPro ASP CONT come

'Where are you coming from?'

\section{Saki West Variety}

(4) a. So ti lo

AUX-2sg PERF go

'Have you gone?'

b. $\mathrm{Ki}$ lo je losen yii

What 2sg-Pro eat afternoon this

'What did you eat this afternoon?'

c. Ngbawo lo de

When 2sg-Pro arrive

'When did you arrive?'

d. Nbo lo ti $n$ bo

Where 2sg-Pro ASP CONT come

'Where are you coming from?'

\section{Kajola Variety}

(5) a. So ti lo

AUX-2sg PERF go

'Have you gone?'

$\begin{array}{clll}\text { b. } K i & \text { lo } & \text { je losen } & y i i \\ \text { What } & \text { 2sg-Pro } & \text { eat afternoon } & \text { this }\end{array}$ 'What did you eat this afternoon?'

c. Nigbawo lo de

When 2sg-Pro arrive

'When did you arrive?' 
Gbenga Fakuade, Lawal Tope Aminat \& Adewale Rafiu

d. Nibo lo $\quad t i \quad n \quad b o$

Where 2sg-Pro ASP CONT come

'Where are you coming from?'

\section{Iseyin Variety}

(6) a. So

ti lo

AUX2-sg PERF go

'Have you gone?'

b. $\mathrm{Ki}$ lo je losen yii

What 2sg-Pro eat afternoon this

'What did you eat this afternoon?'

c. Ngbawo lo de

When 2sg-Pro arrive

'When did you arrive?'

d. Nbo lo ti $n$ bo

Where 2sg-Pro ASP CONT come

'Where are you coming from?'

Atisbo Variety

(7) a. So $\quad t i \quad l o$

AUX-2sg PERF go

'Have you gone?'

b. Kin lo je losen yii

What 2sg-Pro eat afternoon this

'What did you eat this afternoon?'

c. Ngbawo lo de

When 2sg-Pro arrive

'When did you arrive?'

d. $N$ bo lo $t i$ n bo

Where 2sg-Pro ASP CONT come

'Where are you coming from?'

Olorunsogo variety

(8) a. So ti lo

AUX -2sg PERF go

'Have you gone?'

b. Kin lo je losen yii

What 2sg-Pro eat afternoon this

'What did you eat this afternoon?' 


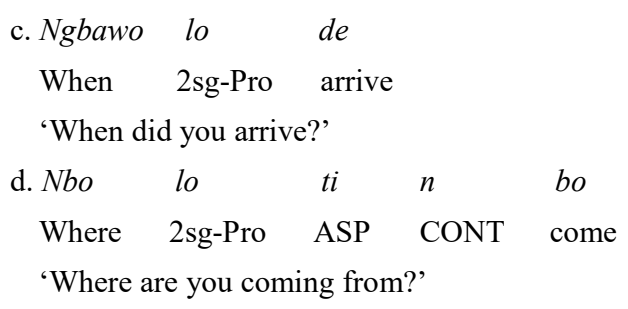

The syntactic variation observed in the sample sentences is captured in Table 10 .

Table 10. Question tags/markers (variants in Onko)

\begin{tabular}{l|l|l|l|l|l|l|l|l}
\hline $\begin{array}{c}\text { Standard } \\
\text { Yoruba }\end{array}$ & $\begin{array}{c}\text { Itesiwaju } \\
\text { LGA }\end{array}$ & $\begin{array}{c}\text { Iwajowa } \\
\text { LGA }\end{array}$ & $\begin{array}{c}\text { Kajola } \\
\text { LGA }\end{array}$ & $\begin{array}{c}\text { Iseyin } \\
\text { LGA }\end{array}$ & $\begin{array}{c}\text { Saki west } \\
\text { LGA }\end{array}$ & $\begin{array}{c}\text { Atisbo } \\
\text { LGA }\end{array}$ & $\begin{array}{c}\text { Olorunsogo } \\
\text { LGA }\end{array}$ & Gloss \\
\hline se & cho & cho & $s o$ & $s o$ & $s o$ & so & so & do/does \\
\hline kinni & $k i$ & $k i$ & $k i$ & $k i$ & $k i$ & $k i n$ & kin & what \\
\hline nibo & nbo & nbo & nbo & nbo & nbo & nbo & nbo & where \\
\hline nigbawo & ngbawo & ngbawo & ngbwo & ngbawo & ngbawo & ngbawo & ngbawo & when \\
\hline
\end{tabular}

Table 10 revealed variation in the use of question markers in Onko dialect. According to the table, where the Standard Yoruba makes use of se 'have', Itesiwaju and Iwajowa use cho 'have' while the remaining five LGAs use so 'have'. For the question marker kinni 'what' in Yoruba, Atisbo and Olorunsogo LGAs adopt kin 'what', while the remaining five LGAs adopt $k i$ 'what'. The question markers nibo 'where' and nigbawo 'when' in Yoruba are realized as nbo and ngbawo in Onko.

The study also revealed that the negative marker $m a$ 'don't' in Standard Yoruba is realized as mee 'don't' in Onko. The following examples further explicate the underlying lexical variation in the use of question markers between the Standard Yoruba and Onko dialect.

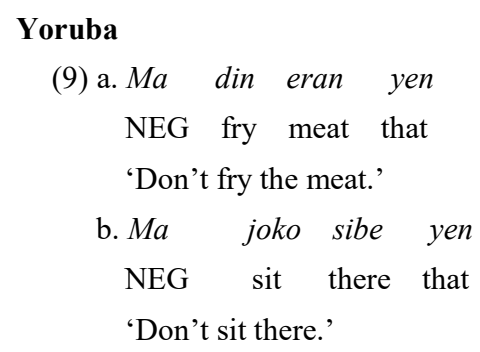

\section{Onko dialect}
(10) a. Mee $\operatorname{din} o$
NEG fry it
'Don't fry the meat.'




\section{Gbenga Fakuade, Lawal Tope Aminat \& Adewale Rafiu}

$$
\begin{aligned}
& \text { b. Mee joko sibe nni } \\
& \text { NEG sit there that } \\
& \text { 'Don't sit there.' }
\end{aligned}
$$

The question markers and negative markers have variants which do not hinder their semantic flow.

\section{Lexical variation in Onko dialect}

Lexical differences play a significant role in regional dialectology. As Rickford (2002) puts it, the difference in vocabulary is an aspect of dialect diversity which people notice

\begin{tabular}{|c|c|c|c|c|c|c|c|c|c|}
\hline No. & $\begin{array}{c}\text { Standard } \\
\text { Yoruba }\end{array}$ & $\begin{array}{c}\text { Itesiwaju } \\
\text { LGA }\end{array}$ & $\begin{array}{c}\text { Iwajowa } \\
\text { LGA }\end{array}$ & $\begin{array}{c}\text { Kajola } \\
\text { LGA }\end{array}$ & $\begin{array}{c}\text { Iseyin } \\
\text { LGA }\end{array}$ & $\begin{array}{c}\text { Saki west } \\
\text { LGA }\end{array}$ & $\begin{array}{c}\text { Atisbo } \\
\text { LGA }\end{array}$ & $\begin{array}{c}\text { Olorunsogo } \\
\text { LGA }\end{array}$ & Gloss \\
\hline 1 & ege & paki & ogege & ege & paki & paki & paki & ege & cassava \\
\hline 2 & $t a b a$ & $t a b a$ & akiya & $t a b a$ & $t a b a$ & $t a b a$ & $t a b a$ & $t a b a$ & tobacco \\
\hline 3 & owu & owututu & aleeni & owu & owu & owu & owu & owututu & cotton \\
\hline$\underline{4}$ & apo & apo & kooli & apo & apo & apo & apo & apo & bag \\
\hline$\underline{5}$ & aso & acho & took & aso & aso & aso & aso & aso & cloth \\
\hline 6 & yara & yara & dodo & yara & yara & yara & yara & yara & room \\
\hline$\underline{7}$ & ekute & ekute & laaka & ekute & ekute & ekute & ekute & ekute & rat \\
\hline$\underline{8}$ & opolo & opolo & lente & opolo & opolo & opolo & opolo & opolo & frog \\
\hline 9 & alangba & alaamo & kiko & alaamo & Alaamo & alangba & alangba & alangba & lizard \\
\hline 10 & efon & yenтиуепте & ijako & уептиуепти & efon & efon & efon & efon & mosquito \\
\hline 11 & efon & efon & anku & efon & efon & efon & efon & efon & buffalo \\
\hline 12 & iyan & iyen & agune & iyen & iyen & iyen & iyen & iyen & pounded yam \\
\hline 13 & aake & aake & edo & aake & aake & aake & aake & aake & axe \\
\hline 14 & eje & epon & eje & eje & eje & eje & eje & eje & blood \\
\hline 15 & lo & chinko & lo & lo & lo & lo & lo & lo & go \\
\hline 16 & igi idana & nchepe & igi idana & igi idana & igi idana & igi idana & igi idana & igi idana & firewood \\
\hline 17 & епи опа & ojupene & епи опе & епи оne & ilo & епu one & ojukone & епи опе & door (way) \\
\hline 18 & akuwori & ekaagbo & akuwoi & alokun & akuwori & akuwori & aloku & aloku & old \\
\hline 19 & sare & sure & fere & sare & sare & sare & sare & sare & run \\
\hline 20 & ebe & ekiti & ebe & ekiti & ebe & ebe & ebe & ebe & ridge \\
\hline
\end{tabular}
readily and comment on quite frequently. From the data collected, the words that differ in the dialect are presented in tabular form for easy comparison.

Looking through Table 11, we can observe lexical variation in Onko dialect. From 
number 1 to 13, the Iwajowa variety exhibits large variations in the words-ogege 'cassava', akiya 'tobacco', aleeni 'owu', kooli 'bag', toko 'cloth', dodo 'room', laaaka 'rat', lente 'frog', kiko 'lizard', ijako 'mosquito' which are all borrowed into Iwajowa variety from Tsabe (Republic of Benin). These words have been in the Iwajowa variety for a very long period that the speakers no longer use their Yoruba equivalents. All the other varieties are similar with the exceptions of number 1,3 and 10 , where there is a preference for a particular word over the other.

From number 14 to 16 , the difference is seen in Itesiwaju LGA, where the other varieties adopt the following lexical items eje 'blood', lo 'go', and igi idana 'firewood', Itesiwaju uses epon 'blood', chinko 'go', nchepe 'firewood' respectively. From number 18 to 20 we also observed variation in the lexical items.

\section{Numeral patterns in Yoruba and Onko dialect}

Every language has a counting system which is specific to it. The numeral pattern has to do with the counting system of a particular language. The process is usually mathematical: it may be addition, subtraction or multiplication. This implies that the numeral system has a particular base which we can add to, subtract from or multiply to generate another word. Yoruba makes use of both addition and subtraction and so does Onko.

Table 12. Numeral pattern in Yoruba and Onko

\begin{tabular}{|c|c|c|c|c|c|c|c|c|c|}
\hline №. & $\begin{array}{c}\text { Standard } \\
\text { Yoruba }\end{array}$ & $\begin{array}{c}\text { Itesiwaju } \\
\text { LGA } \\
\end{array}$ & $\begin{array}{c}\text { Iwajowa } \\
\text { LGA } \\
\end{array}$ & $\begin{array}{c}\text { Kajola } \\
\text { LGA } \\
\end{array}$ & $\begin{array}{c}\text { Iseyin } \\
\text { LGA } \\
\end{array}$ & $\begin{array}{c}\text { Saki. West } \\
\text { LGA } \\
\end{array}$ & $\begin{array}{c}\text { Atisbo } \\
\text { LGA } \\
\end{array}$ & $\begin{array}{c}\text { Olorunsoo } \\
\text { LGA } \\
\end{array}$ & Gloss \\
\hline 1 & ogun & okoo & ogun & ogun & ogun & ogun & ogun & ogun & 20 \\
\hline 2 & okanlelogun & okooleken & mokelelogun & Okanlelogun & mokelelogun & mokenlelogun & mokelelogun & okenlelogunm & $n 21$ \\
\hline 3 & ejilelogun & okoolemejin & mejinlelogun & ejilelogun & mejinlelogun & mejinlelogun & mejinlelogun & ejinlelogun & 22 \\
\hline 4 & etalelogun & okoolemeta & metalelogun & etalelogun & metalelogun & metalelogun & metalelogun & etalelogun & 23 \\
\hline 5 & erinlelogun & okoolemerin & merinlelogun & erinlelogun & merinlelogun & merinlelogun & merinlelogun & erinlelogun & 24 \\
\hline 6 & meedogbon & okoolemarun & meedogbon & edogbon & meedogbon & meedogbon & meedogbon & edoogbon & 25 \\
\hline 7 & erindinlogbon & okoolemefa & erindinlogbon & erindinlogbon & merindinlogbon & merindinlogbon & merindinlogbon & erindinlogbon & 26 \\
\hline 8 & etadinlogbon & okoolemeje & metadinlogbon & etadinlogbon & metadinlogbon & metadinlogbon & metadinlogbon & etadinlogbon & 27 \\
\hline 9 & ejidinlogbon & okoolemejo & mejidinlogbon & ejidinlogbon & mejidinlogbon & mejidinlogbon & mejidinlogbon & ejidinlogbon & 28 \\
\hline 10 & okandinlogbon & okoolemesan & mokandinlogbon & okandinlogbon & mokandinlogbon & mokandinlogbon & mokandinlogbon & okandinlogbon & 29 \\
\hline 11 & ogbon & ogbon & ogbon & ogbon & ogbon & ogbon & ogbon & ogbon & 30 \\
\hline
\end{tabular}

The numeral derivation in Standard Yoruba and Onko is similar. They both derive numeral form using mathematical operations such as addition and subtraction. However, there is an exception which is noticed in the Onko dialect spoken in Itesiwaju LGA. From number 6-9, others deduct while addition is used in Itesiwaju. We observed that this variety 


\section{Gbenga Fakuade, Lawal Tope Aminat \& Adewale Rafiu}

makes use of addition all through, where the other varieties subtract i.e., from twenty-five to twenty-nine, this variety adopts addition. Thus, the Itesiwaju variety uses the addition pattern more than subtraction. It is worthy of noting that variation may not imply total difference. When a dialect or variety uses a linguistic item more than another, there is variation in their usage.

\section{Conclusion}

This study, using a comparative method with copious data, has established the degree of relatedness among the communities that lay claim to the Onko dialect of Yoruba. Obviously, variations in the speech form of these communities were observed. This divergence is not unconnected with the geographical spread of these communities. As observed, the differences are at variance. Specifically, we observed that the communities that are south of the enclave are very close to the standard Yoruba while those that are located in the northern part of the Oke Ogun region exhibit manifest differences. However, these differences are not enough to make Onko dialect unintelligible with the standard variety.

Our data were analyzed and discussed at three different linguistic levels: phonological, syntactic and lexical levels. Our data revealed that certain words are peculiar to some regions. This implies that there is lexical variation between Yoruba and Onko. The study revealed that some words differ in respect to their phonological component and this is termed phonological variation. Some words have extremely different forms; we discovered such words are common in Iwajowa LGA which occurred as a result of language borrowing. The study therefore revealed that there is lexical variation within the Onko varieties.

We discovered that the palato-alveolar affricate $/ \mathfrak{t} /$ is attested in Itesiwaju and Iwajowa LGAs. The alveolar trill $/ \mathrm{r} /$ is often dropped or substituted with glottal fricative $/ \mathrm{h} /$ in Iwajowa. Phonological variation is common between Onko and Standard Yoruba. The variants identified in this study include: $\tilde{\mathrm{a}} \sim \tilde{\mathrm{\varepsilon}}, \mathrm{u} \sim \mathrm{o}, \tilde{\mathrm{u}} \sim \tilde{\mathrm{j}}, \mathrm{i} \sim \tilde{\mathrm{i}}, \mathrm{i} \sim \mathrm{n}, \int \sim \mathfrak{f}$. Such variants like these are termed linguistic variable in the variationist paradigm. The study also discovered that Onko has prenasalized consonant which in actual sense is syllabic.

With respect to our analysis of phonological variation, we discovered that some varieties share certain similarities. The Kajola, Atisbo and Olorunsogo varieties are very similar. The same forms of sound change are common to them. And of all the seven varieties examined, they are the closest to Standard Yoruba. Itesiwaju and Iwajowa varieties are also similar. For instance, the palato-alveolar affricate is attested in the two sub-dialects, and the same form of sound change is observed. The varieties account for the majority of words that brought about lexical variation in the data. The Iseyin and Saki West varieties are also similar and they seem closer to the Itesiwaju and Iwajowa varieties. 


\section{Variation in Onko Dialect of Yoruba}

At the syntactic level, we discovered that Onko and the Standard Yoruba attest the same word order SVO (Subject Verb Object). This study also revealed syntactic variation in Onko. Thus, where Standard Yoruba makes use of se [Se] 'have', Itesiwaju and Iwajowa use cho [50] 'have' while the remaining five LGAS use so [fo] 'have'. For the question marker kinni [kĩni] 'what' in Standard Yoruba, Atisbo and Olorunsogo adopt kin [kĩ] 'what', while the remaining five LGAS adopt $k i$ 'what'. The question markers nibo 'where' and nigbawo 'when' in Yoruba are realized as nbo and ngbawo in Onko.

Similarly, we discovered that the negative marker $m a ́$ ' don't' in Standard Yoruba is realized as méé 'don't' in Onko. From our analysis, we deduced that there is variation in this aspect of question marker in Onko compared with the standard form of Yoruba. Within the Onko dialect, we discovered lexical variation, phonological variation, and syntactic variation. This study revealed two basic factors responsible for variation in Onko dialect.

The two factors are geography (distribution of Onko communities) and language contact. According to Trudgill (1974), social and geographical barriers to communication as well as sheer distance are some of the factors responsible for language variation and in fact it plays an important role in it. We discovered that those communities that cluster together share similar variants while those that are separated by distance speak different variants. This study of Onko dialect revealed there are differences in features from one locality to another, and these differences are however not significant enough to disrupt mutual comprehension. Hence all the variations remain part of the main stock of Onko dialect of the Standard Yoruba.

The second factor is language contact. Millar (2007:387) states that it is very rare, if ever, for a language to find itself spoken in a completely isolated environment, with no contact at all with the speakers of other languages. Most speakers of any given language have day-to-day dealings with the speakers of at least one or two other languages and possibly with a larger number than this. He states further that this ceaseless contact between speakers of different languages has often had substantial consequences for the historical development of those languages. And the single most obvious consequence of language contact is the borrowing of words. The contact between the Onko speakers in Iwajowa with Tsabe people of the Republic of Benin brought about lexical borrowing which results in lexical variation.

This study has revealed variation in the Onko dialect of Yoruba on one hand and the differences between Onko and Yoruba on the other hand. These differences, as the study has shown, were found at the phonological, grammatical and vocabulary levels. The variations are, however, not enough to make the varieties less intelligible with the standard variety (i.e., the Standard Yoruba). 
Gbenga Fakuade, Lawal Tope Aminat \& Adewale Rafiu

\section{References}

Adetugbo, A. 1982. Towards a Yoruba Dialectology [A]. In D. Afolayan (ed.). Yoruba language and Literature [C]. Ibadan: University Press Plc, 207-224.

Adeniyi, H. 2005. Àwon Èka Ėdè Yoruba [A]. In H. R. Adeniyi \& A. A. Ojo (eds.). İlò Èdè àti Èdá-Èdè Yoruba $[\mathrm{C}]$. Trenton, NJ: Africa World Press Inc, 55-68.

Arokoyo, B. 2012. A Comparative Phonology of the Olùkùmi, Igala, Owe and Yoruba Languages [A]. Towards Proto-Niger Congo: Comparison and reconstruction [C]. Paris 18-21, September 2012.

Britain, D. 1997. Dialect Contact, Focusing and Phonological Rule Complexity: The Koineisation of Fenland English [J]. University of Pennsylvania Working Papers in Linguistics, 4(1):141-169.

Chambers, J. \& P. Trudgill. 1998. Dialectology (2nd ed.) [M]. Cambridge: Cambridge University Press.

Gumperz, J. 1958. Dialect Differences and Social Stratification in a North Indian Village [A]. In J. Gumperz (ed.). Language in Social Groups [C]. Stanford, CA: Stanford University Press, 668-682.

Holmes, J. 2013. An Introduction to Sociolinguistics [M]. England: Person.

Holyk, S. (n.d.) Language Variation and Grammatical Change [OL]. Retrieved on 23August, 2017, from: https://www.pulb.sk. Subor.

Millar, M. 2007. Trask's Historical Linguistics [M]. London: Hodder Education.

Oyebade, F. 2001. Igbese Ati Ilana Fonoloji Ede Yoruba [A]. In B. Ajayi (ed.). Ilorin: Department of Linguistics and Nigerian Languages [C]. Nigeria: University of Ilorin, 71-106.

Rickford, J. 2002. How Linguists Approach the Study of Language and Dialect [OL]. Retrieved from: http://www.stanford.edu/.../173 reading ...

Trudgill, P. 1974. The Social Differentiation of English in Norwich [M]. Cambridge: Cambridge University Press.

Wardhaugh, R. 2006. An Introduction to Sociolinguistics [M]. UK: Blackwell Publishing.

Wells, J. 1982. Accents of English [M]. Cambridge: Cambridge University Press.

Winkler, E. 2002. Understanding Language [M]. London: Continuum. 